Rowan University

Rowan Digital Works

$7-23-2020$

\title{
Geological factors impacted cadmium availability and use as an alternative cofactor for zinc in the carbon fixation pathways of marine diatoms
}

Naman Srivastava

Stephanie J. Spielman

Shaunna M. Morrison

Eli K. Moore

Rowan University, mooreek@rowan.edu

Follow this and additional works at: https://rdw.rowan.edu/see_facpub

Part of the Earth Sciences Commons, and the Environmental Sciences Commons

\section{Recommended Citation}

Srivastava, Naman; Spielman, Stephanie J.; Morrison, Shaunna M.; and Moore, Eli K., "Geological factors impacted cadmium availability and use as an alternative cofactor for zinc in the carbon fixation pathways of marine diatoms" (2020). School of Earth \& Environment Faculty Scholarship. 47.

https://rdw.rowan.edu/see_facpub/47

This Article is brought to you for free and open access by the School of Earth \& Environment at Rowan Digital Works. It has been accepted for inclusion in School of Earth \& Environment Faculty Scholarship by an authorized administrator of Rowan Digital Works. 


\title{
Geological factors impacted cadmium availability and use as an alternative cofactor for zinc in the carbon fixation pathways of marine diatoms
}

\author{
Naman Srivastava ${ }^{1,2}$, Stephanie J. Spielman ${ }^{1}$, Shaunna M. Morrison ${ }^{3}$, Eli K. Moore ${ }^{2}$ \\ ${ }^{1}$ Department of Biological Sciences, College of Science and Mathematics, Rowan University, \\ Glassboro, NJ, United States \\ ${ }^{2}$ Department of Environmental Science, School of Earth and the Environment, Rowan \\ University, Glassboro, NJ, United States \\ ${ }^{3}$ Earth and Planets Laboratory, Carnegie Institution for Science, Washington, DC, United States \\ Corresponding Author: Eli K. Moore (mooreek@rowan.edu)
}

\section{Key Points:}

- $\quad \mathrm{Cd}$ and Zn share similar sulfide mineral chemistry and weatherability

- Sulfur-containing Cd minerals are often co-located with sulfur-containing Zn sulfide minerals

- Simultaneous weathering of sulfur-containing $\mathrm{Cd}$ and $\mathrm{Zn}$ minerals allows $\mathrm{Cd}$ to be a substitute for $\mathrm{Zn}$ in protein complexes during periods of $\mathrm{Zn}$ depletion 


\section{Abstract}

Transition metal cofactors are crucial for many biological processes. Despite being

3 primarily considered to be toxic, the transition metal cadmium $(\mathrm{Cd})$ was discovered to be a

4 substitute for zinc $(\mathrm{Zn})$ in photosynthetic carbon fixation pathways in marine diatoms. However,

5 it is not known how conditions in the geosphere impacted $\mathrm{Cd}$ availability and its incorporation as

6 an alternative metal cofactor for phytoplankton. We employed mineral chemistry network analysis

7 to investigate which geochemical factors may have influenced the availability of $\mathrm{Cd}$ and $\mathrm{Zn}$ during

8 the putative time period that alternative Cd-based pathway evolved. Our results show that $\mathrm{Zn}$

9 minerals are more chemically diverse than are $\mathrm{Cd}$ minerals, but $\mathrm{Zn}$ - and $\mathrm{Cd}$-containing minerals

10 have similar mean electronegativities when specifically considering sulfur (S)-containing species.

11 Cadmium and zinc sulfides are the most common Cd- and Zn-containing mineral species over the

12 past 500 million years. In particular, the $\mathrm{Cd}$ and $\mathrm{Zn}$ sulfides, respectively greenockite and

13 sphalerite, are highly abundant during this time period. Furthermore, S-containing Cd- and $\mathrm{Zn}$

14 minerals are commonly co-located in geologic time, allowing them to be weathered and

15 transported to the ocean in tandem, rather than occurring from separate sources. We suggest that

16 the simultaneous weathering of $\mathrm{Cd}$ and $\mathrm{Zn}$ sulfides allowed for $\mathrm{Cd}$ to be a bioavailable direct

17 substitute for $\mathrm{Zn}$ in protein complexes during periods of $\mathrm{Zn}$ depletion. The biogeochemical cycles

18 of $\mathrm{Zn}$ and $\mathrm{Cd}$ exemplify the importance of the coevolution of the geosphere and biosphere in

19 shaping primary production in the modern ocean. 


\section{Plain Language Summary}

21

Cadmium $(\mathrm{Cd})$ is a toxic heavy metal in biology, but the element is also used as an

22 alternative cofactor for zinc $(\mathrm{Zn})$ in carbon fixation proteins of productive marine phytoplankton

23 called diatoms. It is not known how a toxic metal became available for biological utilization during

24 periods of diatom evolution. In this study we used network analysis of the chemistry of $\mathrm{Cd}$ and $\mathrm{Zn}$

25 minerals over billions of years of Earth history to better understand how these elements are related.

26 Our results show that the chemistry of $\mathrm{Zn}$ minerals is much more diverse than for Cd minerals, but

27 the two elements are similar in terms of their sulfur-containing mineral chemistry in geologic time.

28 Cadmium sulfides are also commonly co-located with $\mathrm{Zn}$ sulfides, which are both highly

29 weatherable. Simultaneous weathering of $\mathrm{Cd}$ and $\mathrm{Zn}$ sulfides make $\mathrm{Cd}$ a bioavailable substitute

30 for $\mathrm{Zn}$ in protein complexes during periods of $\mathrm{Zn}$ depletion. 


\section{Introduction}

Transition metals are crucial cofactors in many biological processes across the tree of life (Holm, Kennepohl, and Solomon 1996; Dey et al. 2007; Hosseinzadeh and Lu 2016). The evolving geosphere and biosphere impacted the availability of metal cofactors and emergence of metabolic pathways in geologic time (Dupont et al. 2006; Moore et al. 2017). Deep-time changes in the geosphere and biosphere provide insight into how the relationship between the two spheres became so intertwined. The transition metal cadmium $(\mathrm{Cd})$ is toxic to many biological systems (Flick, Kraybill, and Dlmitroff 1971; Das, Samantaray, and Rout 1997). Exposure to Cd results in the production of hydrogen peroxide and the breakdown of cellular phospholipid bilayers (Khan et al. 2013), and Cd's ability to directly attack and damage DNA makes Cd a potent carcinogen (Coogan, Bare, and Waalkes 1992; Giaginis, Gatzidou, and Theocharis 2006).

Despite Cd's predominantly toxic effects, there are several known instances where Cd in fact participates beneficially in biological pathways. For example, $\mathrm{Cd}$ is able to substitute for zinc ( $\mathrm{Zn}$ ) at certain functional Zn-binding protein sites, such as the pyrimidine (a type of DNA nucleotide) biosynthesis enzyme aspartate transcarbamoylase (Rosenbusch and Weber 1971). Cd is also known to serve as an alternative cofactor in the Carbonic Anhydrase (CA) enzyme, which

47 is involved in acquiring dissolved $\mathrm{CO}_{2}$ for photosynthesis, of marine diatoms (Price and Morel 48 1990; Lane and Morel 2000; Park, Song, and Morel 2007). While Zn is a more energetically efficient CA cofactor, Cd can function as an effective substitute when $\mathrm{Zn}$ availability is low (Lane et al. 2005; Xu et al. 2008). Cadmium therefore possesses a micronutrient profile in marine systems

51 with lower concentrations in surface waters ( 0.1 to $0.5 \mathrm{nmol}\left[\mathrm{Cd}^{2+}\right] / \mathrm{kg}$ seawater) and increasing

52 concentrations in deeper waters $\left(\sim 1.0 \mathrm{nmol}\left[\mathrm{Cd}^{2+}\right] / \mathrm{kg}\right.$ seawater) (Boyle, Sclater, and Edmond 53 1976). The gradient of $\mathrm{Cd}$ is formed based on light penetration, how deep phytoplankton live, their 
54 ability to sustain photosynthesis, and nonspecific uptake and $\mathrm{Cd}$ homeostasis in microbial cells

55 (Horner et al. 2013). The concentration of $\mathrm{Cd}$ in seawater is below the level of Cd toxicity

56 responses in the marine diatom Thalassiosira nordenskioeldii (Wang and Wang 2008).

57 Basalt, on average, contains approximately 120 parts per billion (ppb) of Cd, and is a major

58 source of $\mathrm{Cd}$ to the ocean due to weathering and the prevalence of basalt in oceanic crust (Yi et al.

59 2000). Hydrothermal fluids are also major sources of $\mathrm{Cd}$ to the ocean, with Cd concentrations up

60 to $2 \mathrm{nM}$ (Douville et al. 2002). Natural emission of Cd occurs primarily from volcanoes, followed

61 by biogenic sources, aeolian transport, terrestrial biomass burning, and sea-salt spray (Jerome O.

62 Nriagu 1989; Cullen and Maldonado 2013). Cadmium deposition and cycling varies across

63 different environmental conditions (Kelly et al. 2001; Yee and Fein 2001), specifically among

64 saltwater, freshwater, and soil environments (Gerth and Brümmer 1983; Bruemmer, Gerth, and

65 Tiller 1988; Barrow, Gerth, and Brümmer 1989; Lock and Janssen 2003). Within freshwater

66 ecosystems, Cd's availability and toxicity strictly depends on the element's distributional

67 speciation with organic matter due to concentration and characteristics of dissolved organic

68 carbon, $\mathrm{pH}$, and cations in solution (Sigg and Behra 2005). Upon transitioning into more saline

69 waters, cationic interactions increase Cd mobility and solubility (Duce et al. 1991). When Cd

70 interacts with soils and minerals, factors such as redox potential, $\mathrm{pH}$, and organic ion presence

71 influence its bioavailability (Lock and Janssen 2003). The wide range of interactions between Cd

72 and the environment create a cascade of reactions that have varying impacts on the solubility and

73 mobility of $\mathrm{Cd}$ in the environment. These processes therefore have a dramatic effect on the

74 formation of an equilibration cycle between soil runoff and water cycling.

Various aspects of the biological pathways involving $\mathrm{Cd}$ have been well documented

76 (Rosenbusch and Weber 1971; Beyersmann and Hechtenberg 1997; Lane and Morel 2000; Lane 
77

78

79

80

81

82

et al. 2005; Park, Song, and Morel 2007; Xu et al. 2008), but it is not fully known how the geosphere impacted the availability of $\mathrm{Cd}$ and evolution of associated biological pathways. Saito et al. (Saito, Sigman, and Morel 2003) showed that the dissolved concentrations of Cd in the ocean would have been altered by changing ocean chemistry at different stages of Earth history. Although oceanic basalt and hydrothermal vents are likely the main sources of Cd to the ocean (Yi et al. 2000), minerals are important for understanding the geochemistry and solubility of both Cd and $\mathrm{Zn}$ to the ocean from geological sources through weathering processes (Bertine and Goldberg 1971; Callender 2003; Cullen and Maldonado 2013). Here, we examine the mineral records of Cd and $\mathrm{Zn}$ in order to compare the chemistry and location of potentially weatherable $\mathrm{Cd}$ and $\mathrm{Zn}$ mineral sources to the environment at different periods of Earth history relevant to the emergence of marine diatoms and the utilization of $\mathrm{Cd}$ as a cofactor in carbonic anhydrase. This study considers $\mathrm{Cd}$ and $\mathrm{Zn}$ minerals to be those in which $\mathrm{Cd}$ and $\mathrm{Zn}$ are listed in the chemical formula, as defined by the International Mineralogical Association (IMA); lists of IMA-defined Cd and Zn minerals can be found at https://rruff.info/ima/.

\section{Methods}

\subsection{Mineral chemistry network analysis}

Network analysis has emerged as a powerful technique to investigate mineral evolution and mineral ecology (Morrison et al. 2017; Hystad, Morrison, and Hazen 2019; Hazen et al. 2019). Bipartite mineral chemistry network analysis includes two classes of nodes, minerals and chemical elements, with network edges connecting each mineral node to each one of its constituent element nodes. The bipartite network method has recently been applied to understand redox evolution of cobalt and vanadium and their bioavailability in the Archean ocean (Moore et al. 2018; 2020). Bipartite network analysis of $\mathrm{Cd}$ and $\mathrm{Zn}$ mineral chemistry was performed using the $\mathrm{R}$ package 
100

101

102

103

104

105

106

107

108

109

110

111

112

113

114

115

116

117

118

119

120

121

122

dragon (Spielman 2019). Specifically, we examined Cd's bipartite mineral chemistry network across the three time periods of $\geq 2.7$ billion years ago $(\mathrm{Ga}), \geq 0.6 \mathrm{Ga}$, and $\geq 0.2$. The time range of $\geq 2.7 \mathrm{Ga}$ was selected because only one $\mathrm{Cd}$ mineral has a maximum (i.e. oldest) known age of $\geq 2.8$ $\mathrm{Ga}$ (greenockite). The time range of $\geq 0.6 \mathrm{Ga}$ was selected as it is positioned at the beginning of an increase in preserved $\mathrm{Cd}$ mineral and $\mathrm{Zn}$ mineral localities [(Golden et al. 2019) http://rruff.info/evolution/]. The time range of $\geq 0.2 \mathrm{Ga}$ was selected as this period approximately coincides with the oldest known evidence for the origin of diatoms (Kooistra and Medlin 1996; Sims, Mann, and Medlin 2006; Falkowski and Knoll 2007). Indeed, diatoms are the only organisms known to use the alternative Cd-CA protein (Alterio et al. 2015). We performed a PSIBLAST search against the $n r$ database (all non-redundant proteins sequences in NCBI) to identify any orthologous sequences to the known Cd-CA protein from the marine diatom Thalassiosira weissflogii (PDB ID 3BOB).

Louvain community detection cluster analysis (Blondel et al. 2008) was performed using dragon to identify associations between minerals and elements in the $\mathrm{Cd}$ and $\mathrm{Zn}$ combined mineral chemistry network. The Louvain community detection method was chosen for this study because of the algorithm's optimization of modularity for grouping network nodes by measuring the density of network edges inside of network communities to edges outside network communities (Blondel et al. 2008). The Louvain method is a greedy optimization method, and is similar to the network community detection method by Clauset et al. (Clauset, Newman, and Moore 2004). Mean mineral electronegativity is calculated as the unweighted average of each mineral's constituent element electronegativities.

Mineral data were compiled for analysis from the Mineral Evolution Database [(Golden et al. 2019) http://rruff.info/evolution/; Accessed June 19 $\left.{ }^{\text {th }}, 2019\right]$. Co-located Cd minerals and Zn 
123 minerals were identified by comparing Mindat locality ID numbers of $\mathrm{Cd}$ minerals and $\mathrm{Zn}$

124 minerals, including $\mathrm{Cd}$ minerals and $\mathrm{Zn}$ minerals that contain sulfur (S), catalogued in the Mineral

125 Evolution Database [(Golden et al. 2019) http://rruff.info/evolution/]. Minerals with the same

126 Mindat locality ID number are defined as co-located in this analysis.

\section{3. Results}

Evolving mineral chemistry bipartite networks can be used to examine the relationships

129 between minerals and the chemical elements in their ideal chemical formulas through deep-time

130 (Spielman 2019). Figure 1 represents the evolution of $\mathrm{Cd}$ mineral chemistry bipartite networks

131 from the oldest known samples into modern day, clearly illustrating the limited mineral chemistry

132 network expansion prior to $0.6 \mathrm{Ga}$ and the subsequent dramatic expansion after 0.6 Ga [(Golden

133 et al. 2019); http://rruff.info/evolution/, Accessed June 19 $\left.{ }^{\text {th }}, 2019\right]$. Sulfur is the most common

134 element found to form as a major constituent in $\mathrm{Cd}$ minerals at all time periods of $\mathrm{Cd}$ 135 mineralization, with 270 known localities and 16 minerals with $\mathrm{Cd}$ and $\mathrm{S}$ in their ideal chemical

136 formula. Cadmium minerals containing $\mathrm{S}$ account for $92 \%$ of all dated $\mathrm{Cd}$ mineral localities in the

$137 \mathrm{MED}$, with 8 of the $11 \mathrm{Cd}$ minerals with maximum known ages older than $1.8 \mathrm{Ga}$ containing $\mathrm{S}$.

138 The Cd-sulfide greenockite, CdS, is the oldest known Cd mineral currently recorded in the MED

139 (maximum age of $4.0 \mathrm{Ga}$ ) and has the most reported localities of all $\mathrm{Cd}$ minerals (196 localities).

140 Hawleyite, CdS, has the second most localities at 30 but with a significantly younger maximum

141 known age of $2.74 \mathrm{Ga}$. Oxygen is the second most common element known to form Cd minerals,

142 with 14 minerals containing $\mathrm{Cd}$ and $\mathrm{O}$ in their ideal chemical formula and 41 known localities in

143 the MED. Cadmoselite, CdSe, has the oldest maximum known age (2.72 Ga) among Cd minerals

144 that do not contain $\mathrm{S}$ or $\mathrm{O}$ as an essential constituent. Arsenic, As, and lead, $\mathrm{Pb}$, become more 
145 prominent mineral forming elements with $\mathrm{Cd}$ from 0.6 to $0.2 \mathrm{Ga}$ as the number of $\mathrm{Cd}$ minerals and 146 localities increases leading up to present day.

Cadmium and zinc both belong to periodic table group 12 (same outer shell electron 148 configuration) and the two elements have similar chemical properties, but $\mathrm{Zn}$ is approximately 149650 times more abundant than $\mathrm{Cd}$ in the Earth's crust $[\mathrm{Zn}=65.5 \mathrm{ppm} ; \mathrm{Cd}=0.102 \mathrm{ppm}$; (Wedepohl 150 1995)] and forms a larger number of minerals with a wider range of elements than Cd (Figure 2). 151 In particular, $\mathrm{O}$ and $\mathrm{H}$ form minerals with $\mathrm{Zn}$ much more commonly than with $\mathrm{Cd}$ : $\mathrm{Zn}$ forms nearly 15216 times more minerals with $\mathrm{O}$ than $\mathrm{Cd}$ forms with $\mathrm{O}$, with $89 \%$ of $\mathrm{Zn}$ minerals and $57 \%$ of $\mathrm{Cd}$ 153 minerals containing $\mathrm{O}$. Zinc forms nearly 18 times more minerals with $\mathrm{H}$ than $\mathrm{Cd}$ forms with $\mathrm{H}$, 154 with $72 \%$ of $\mathrm{Zn}$ minerals and $43 \%$ of $\mathrm{Cd}$ minerals containing $\mathrm{H}$. Additionally, $\mathrm{Zn}$ minerals that 155 contain $\mathrm{O}$ or $\mathrm{H}$ are found at many more localities (4,110 localities) than $\mathrm{Cd}$ minerals that contain $156 \mathrm{O}$ or $\mathrm{H}$ (41 localities). Zinc minerals that contain $\mathrm{O}$ and $\mathrm{H}$ also contain various other common 157 mineral forming elements that do not form minerals with Cd (e.g. silicon, magnesium, sodium, 158 titanium, etc.; Figure 2). Conversely, $\mathrm{Zn}$ forms only approximately 4 times more minerals with $\mathrm{S}$ 159 than Cd forms with S, with only $25 \%$ of $\mathrm{Zn}$ minerals containing S while $64 \%$ of Cd minerals 160 contain S. Despite the larger number of elements that form minerals with $\mathrm{Zn}$ than $\mathrm{Cd}$, $\mathrm{Zn}$ minerals 161 that contain sulfur still make up the majority of all known Zn mineral localities (62\%). Similarly 162 to $\mathrm{Cd}$ and greenockite, the $\mathrm{Zn}$ sulfide mineral sphalerite is found at by far the largest number of 163 known localities (>4,500 localities). Louvain community detection (Blondel et al. 2008) was used to identify mineral element associations between $\mathrm{Cd}, \mathrm{Zn}$, and their mineral forming elements, while accounting for the number of mineral localities. In the Cd-Zn combined network, Cd clusters with $\mathrm{S}$, the abundant $\mathrm{Cd}$ sulfide minerals greenockite and hawleyite, the abundant $\mathrm{Zn}$ sulfide sphalerite, and other abundant $\mathrm{Zn}$ 
168 169

170

171

172

173

174

175

176

177

178

179

180

181

182

183

184

185

186

187

188

189

190

sulfides (Figure 3). Other common mineral-forming elements for both $\mathrm{Cd}$ and $\mathrm{Zn}$ include $\mathrm{O}, \mathrm{H}$, $\mathrm{As}, \mathrm{Fe}, \mathrm{Cu}$, and $\mathrm{Pb}$. Zinc and $\mathrm{O}$ each cluster separately given the wide range of other elements that $\mathrm{Zn}$ and $\mathrm{O}$ each form minerals with, but overall there is a great deal of mineral chemistry overlap between network clusters 3 ( $\mathrm{Zn}$ cluster) and 5 (Oxygen cluster). Far less mineral chemistry overlap occurs between cluster 1 (Cd and S cluster) and other network clusters (Figure 3), showing that the main chemical similarities between $\mathrm{Cd}$ and $\mathrm{Zn}$ minerals exist among $\mathrm{Cd}$ and $\mathrm{Zn}$ minerals that contain S.

The number of co-located S-containing $\mathrm{Cd}$ and $\mathrm{Zn}$ minerals increases through geologic time, accounting for the vast majority (87\%) of all co-located $\mathrm{Cd}$ and $\mathrm{Zn}$ minerals (Figure 4). Colocated non-S-containing $\mathrm{Cd}$ minerals and non-S-containing Zn minerals make up a much smaller portion of co-located $\mathrm{Cd}$ minerals and $\mathrm{Zn}$ minerals as illustrated in Figure 4. The majority (81\%) of co-located $\mathrm{Cd}$ minerals and $\mathrm{Zn}$ minerals occur from 0.6 Ga to present day (Figure 4). $\mathrm{Cd}$ minerals have a narrower range of mean mineral electronegativity values than $\mathrm{Zn}$ minerals $(\mathrm{Cd}$ mean mineral electronegativity range $=1.97$ to 2.565 ; $\mathrm{Zn}$ mean mineral electronegativity range $=$ 1.61 to 2.7; pure $\mathrm{Cd}$ and $\mathrm{Zn}$ mean mineral electronegativities are not included), which coincides with the greater chemical diversity of $\mathrm{Zn}$ minerals compared to $\mathrm{Cd}$ minerals (Figure 5). Furthermore, minerals that contain both $\mathrm{Zn}$ and $\mathrm{S}$ also have a narrow range of mean mineral electronegativity values through geologic time (mean mineral electronegativity range of Scontaining $\mathrm{Zn}$ minerals $=1.737$ to 2.582 ) that is more similar to Cd minerals (Figure 6), illustrating the chemical similarities and, therefore, propensity towards similar weathering rates of $\mathrm{Cd}$ minerals and S-containing Zn minerals.

The PSI-BLAST search performed using the seed Cd-CA sequence from the marine diatom Thalassiosira weissflogii (PDB ID 3BOB) did not reveal any related sequences. Therefore, it is 
191 either possible that the Cd-CA is a lineage-specific evolutionary innovation in these diatom

192 species, or further environmental metagenomics studies may reveal other species which also 193 possess this protein.

194

195

\section{Discussion}

The mineral chemistry of Cd throughout Earth's history is less extensive compared to many other transition metals, however, the element's chemical associations and mineral formation with S (Figures 1-3) are important to Cd geochemical cycling (Saito, Sigman, and Morel 2003). Cadmium sulfides readily precipitate under acidic and alkaline conditions (Milligan 1934; Rittner and Schulman 1943), and are known to be highly weatherable (Bertine and Goldberg 1971; Callender 2003; Cullen and Maldonado 2013). Weathered Cd sulfides or trace amounts of Cd associated with $\mathrm{S}$ in basalt can therefore represent a potential source of $\mathrm{Cd}$ to the environment, particularly given the relative abundance of S-containing $\mathrm{Cd}$ minerals compared to all other $\mathrm{Cd}$ minerals (Figure 1). Conversely, Zn is roughly 650 times more abundant than $\mathrm{Cd}$ in the Earth's crust (Wedepohl 1995), which largely contributes to the existence of many more $\mathrm{Zn}$ mineral species than $\mathrm{Cd}$ mineral species, and the occurrence of $\mathrm{Zn}$ minerals at a much larger number of localities than Cd minerals [(Golden et al. 2019) http://rruff.info/evolution/]. However, similar to $\mathrm{Cd}$, the high relative abundance of S-containing $\mathrm{Zn}$ mineral localities compared to all other $\mathrm{Zn}$ minerals (Figures 2, 3), and the high weatherability of Zn sulfides (Stanton 2005; Robson et al. 2014), indicate that $\mathrm{Zn}$ sulfides represent a potential source of $\mathrm{Zn}$ to the environment.

Despite the differences in mineral chemistry between $\mathrm{Cd}$ and $\mathrm{Zn}$, the S-containing minerals and sulfide complexation of the two elements share certain characteristics in common. Approximately $64 \%$ of $\mathrm{Cd}$ mineral species contain $\mathrm{S}$, while only $25 \%$ of $\mathrm{Zn}$ minerals contain $\mathrm{S}$, 
213 resulting in $\mathrm{Cd}$ and $\mathrm{S}$ clustering together in the combined $\mathrm{Cd}-\mathrm{Zn}$ mineral chemistry network

214 (Figure 3). Multiple $\mathrm{Zn}$ and Cd sulfide compounds have comparable stability constants and display 215 similar dissolved concentration fluctuations in response to changing conditions in seawater (Zhang 216 and Millero 1994; Luther et al. 1996; Al-Farawati and van den Berg 1999; Cutter, S. Walsh, and 217 Silva de Echols 1999). Furthermore, bioinorganic chemistry modelling work by Saito et al. (Saito, 218 Sigman, and Morel 2003) demonstrated that dissolved concentrations of both Cd and Zn would 219 have been significantly lower than present day in the ferro-sulfidic ocean of the Archean eon (Shen, 220 Buick, and Canfield 2001), and even lower still in the sulfidic ocean of the Proterozoic eon (D. E. 221 Canfield 1998; Poulton, Fralick, and Canfield 2004). The importance of late-evolving Zn-binding 222 proteins in Eukaryotes, and the increased bioavailability $\mathrm{Zn}$ in oxygenated waters of the 223 Phanerozoic eon indicate that Zn was a crucial cofactor in eukaryotic evolution (Dupont et al. 224 2006; 2010). Mineral chemistry can shed additional light on the biogeochemical links between Cd 225 and Zn described in Saito et al. (Saito, Sigman, and Morel 2003) by characterizing chemical 226 associations of the two elements.

The closer overlapping range of mean mineral electronegativity between $\mathrm{Cd}$ minerals and 228 S-containing $\mathrm{Zn}$ minerals represents similar chemical attributes between $\mathrm{Cd}$ minerals and S229 containing Zn minerals compared to all other non-S-containing Zn minerals (Figures 5, 6). Our 230 results show that the common co-location of S-containing $\mathrm{Cd}$ and $\mathrm{Zn}$ minerals (Figure 4), in 231 concert with the similar stability constants of $\mathrm{Cd}$ sulfides and $\mathrm{Zn}$ sulfides in seawater (Zhang and 232 Millero 1994; Luther et al. 1996; Al-Farawati and van den Berg 1999; Cutter, S. Walsh, and Silva 233 de Echols 1999), would result in simultaneous weathering and availability of $\mathrm{Cd}$ and $\mathrm{Zn}$ to the 234 environment. Co-weathering of S-containing $\mathrm{Cd}$ and $\mathrm{Zn}$ minerals would result in a direct source 235 of $\mathrm{Cd}$ to marine diatoms after $\mathrm{Zn}$ is depleted, and greater access to $\mathrm{Cd}$ as an alternative cofactor 
236 than if the element was weathered from a distant separate source that is not directly linked through

237 aqueous/marine transport. The mutual mineral chemistry properties (Figures 3, 5, 6) and shared

238 localities (Figure 4) of S-containing Cd and Zn minerals allow for weatherability and simultaneous

239 transport of $\mathrm{Cd}$ and $\mathrm{Zn}$ to marine waters, thus supporting the biogeochemical link between the two

240 elements described in Saito et al. (Saito, Sigman, and Morel 2003).

241 Similar chemical and physical properties of $\mathrm{Cd}$ and $\mathrm{Zn}$ underscore the various geochemical

242 links between the two elements. Cadmium and zinc are both group 12 elements in the periodic

243 table with similar electron configuration, and both elements predominantly occur in the $\mathrm{Cd}^{2+}$ and

$244 \mathrm{Zn}^{2+}$ redox states (J. O. Nriagu 1980). Significant sources of Cd in Earth's crust occur as surface

245 coatings with the abundant $\mathrm{Zn}$ sulfides sphalerite and wurtzite, and certain $\mathrm{Zn}$ silicates and

246 carbonates can contain up to $1.25 \%$ concentration of Cd (Fleischer et al. 1974; Gong, Rose, and

247 Suhr 1977; J. O. Nriagu 1980). Sphalerite generally contains 0.2 to $1.0 \mathrm{wt} \%$ Cd, and in some cases

248 Cd content in sphalerite can be as high 13.2 wt.\% (Cook et al. 2009). Additionally, Cd was first

249 isolated and identified as a trace metal impurity in Zn carbonates (Cullen and Maldonado 2013).

250 Therefore, the weathering of trace amounts of $\mathrm{Cd}$ associated with $\mathrm{Zn}$ minerals, particularly the

251 highly abundant mineral sphalerite, would be an additional simultaneous source of both $\mathrm{Cd}$ and

$252 \mathrm{Zn}$ to the environment in addition to the weathering of co-located $\mathrm{Cd}$ - and $\mathrm{Zn}$-containing minerals

253 and basalts. Due to tectonic processes, there is a greater probability that older rocks and minerals

254 will be subducted and lost to the mantle, resulting in greater preservation of younger minerals

255 (Taylor and McLennan 1995; Rapp and Watson 1995) and potential age bias in some data from

256 the Mineral Evolution Database. The maximum known mineral ages and associated references of

257 Archean and Proterozoic Cd minerals are given in Supplementary Table S1. 
The comparable mineral chemistry and common co-occurrence of $\mathrm{Cd}$ and $\mathrm{Zn}$ appear to be

259

260

261

262

263

264

265

266

267

268

269

270

271

272

273

274

275

276

277

278

279

280

important in the shared biological functions of $\mathrm{Cd}$ and $\mathrm{Zn}$ in carbonic anhydrase (CA) as well.

Carbonic anhydrase is a globally significant enzyme that catalyzes the interconversion of $\mathrm{CO}_{2}$ and $\mathrm{HCO}_{3}{ }^{-}$in photosynthetic organisms to fix carbon (Meldrum and Roughton 1933; Wilbur and Anderson 1948; Badger and Price 1994). Zinc is a crucial cofactor in the function of carbonic anhydrase, but it has also been discovered that $\mathrm{Cd}$ can serve as an alternative metal cofactor in CA for marine diatoms when $\mathrm{Zn}$ is depleted in the environment (Price and Morel 1990; Lane and Morel 2000; Lane et al. 2005; Park, Song, and Morel 2007; Xu et al. 2008). Diatoms are highly productive primary producers that rapidly deplete nutrients in surface waters during blooms and influence global Zn biogeochemistry (Vance et al. 2017). It has also been shown that Zn may limit primary production in diatom dominated sub-arctic waters (Coale 1991; Crawford et al. 2003). Therefore, the weathering and availability of co-located S-containing $\mathrm{Cd}$ and $\mathrm{Zn}$ minerals, and trace $\mathrm{Cd}$ in $\mathrm{Zn}$ minerals, may support CA function and primary production by diatoms during Zn scarcity.

Although several classes of CA proteins exist, $\mathrm{Cd}$ is only found in one specific class of CA ( $\zeta$-CA) which has an overall unique amino acid residue structure surrounding the metal cofactor ion (i.e. Zn or Cd) (Xu et al. 2008; Amata et al. 2011; Alterio et al. 2012). In contrast, Zn carbonic anhydrase occurs in a wide range of taxa (Pinter and Stillman 2014; Supuran 2016). The diatoms that are known to use $\mathrm{Cd}$ during periods of $\mathrm{Zn}$ scarcity prefer $\mathrm{Zn}$ when it is available, due to the greater enzymatic efficiency and faster yield rate of inorganic carbon when using $\mathrm{Zn}$ as the metal cofactor (Lane et al. 2005; Xu et al. 2008). The only other class of CAs known to have a similar structure to $\zeta-\mathrm{CA}$ is $\beta$-CA, such that both enzymes have 2 cysteine residues and 1 histidine residue that bind either $\mathrm{Zn}$ or $\mathrm{Cd}$ (Xu et al. 2008; Supuran 2016). The shared structures of $\zeta$-CA and $\beta$-CA suggest an evolutionary link between the two protein classes, and may be a topic of evolutionary 
281 divergence given that $\beta$-CA synthesizing organisms are largely photosynthetic plants and algae, 282 while $\zeta$-CA synthesizing organisms are a specific group of marine diatoms (Sültemeyer 1998; 283 Moroney, Bartlett, and Samuelsson 2001; Amata et al. 2011).

284 Despite the structural similarities between $\zeta$-CA and $\beta$-CA, organisms that synthesize $\beta$ 285 CA do not use Cd as an alternative cofactor to Zn (Day and Franklin 1946; Rowlett 2010). This is 286 because $\beta$-CA synthesizing organisms exhibit a normal toxic response to $\mathrm{Cd}$ exposure. 287 Phytochelatins (PC) are crucial proteins found in $\zeta$-CA synthesizing organisms that serve to 288 transport $\mathrm{Cd}$ ions to the CA complex for carbon fixation and inhibit the toxic shock response 289 diatoms experience when taking in $\mathrm{Cd}$ ions, thus allowing $\mathrm{Cd}$ to be utilized in the $\mathrm{CA}$ metal 290 cofactor site (Ahner, Kong, and Morel 1995; Lee, Ahner, and Morel 1996; Wu et al. 2016).

291 Phytochelatin synthase proteins are activated by the presence of $\mathrm{Cd}$ and other potentially toxic ions 292 [ex: Arsenic, As; (Uraguchi et al. 2017; Schmöger, Oven, and Grill 2000)], and the PC proteins 293 themselves are composed from Glutathione (Cysteine, Glutamic acid, and Glycine), which 294 function to form tight covalent bonds around the metallic ions (i.e. chelation) (Grill, Winnacker, 295 and Zenk 1985; Grill et al. 1989). The evolution of PC proteins was thus crucial for the utilization 296 of $\mathrm{Cd}$ by diatoms when $\mathrm{Zn}$ is unavailable in the environment. The oldest known diatom fossils are approximately 180 million years old (Kooistra and 298 Medlin 1996; Sims, Mann, and Medlin 2006; Falkowski and Knoll 2007), which occurs after the 299 oxygenation of the oceans (D. E. Canfield 1998; Scott et al. 2008) and subsequent increase in Zn 300 and Cd bioavailability in ocean waters (Saito, Sigman, and Morel 2003). Phanerozoic continental 301 weathering was also enhanced by the colonization of land by terrestrial plants (Berner 1992), 302 which could have impacted the mobilization of co-located S-containing $\mathrm{Cd}$ and $\mathrm{Zn}$ minerals 303 (Figure 4) to coastal waters. Given that diatoms are known to be highly productive primary 
304 producers that quickly use up available dissolved nutrients (Furnas 1990; Armbrust 2009;

305 Mahadevan et al. 2012), the availability of Cd from weathered S-containing minerals following 306 rapid $\mathrm{Zn}$ depletion by highly productive diatom blooms may have influenced the evolution of $\zeta$ 307 CA and PCs involved in Cd utilization.

\section{Conclusions}

Despite the limited mineral chemistry of $\mathrm{Cd}$, the relative abundance of highly weatherable S-containing Cd minerals compared to other Cd minerals, and the co-location of S-containing Cd and $\mathrm{Zn}$ minerals were likely contributing factors in the availability and utilization of $\mathrm{Cd}$ as an

312 alternative cofactor to $\mathrm{Zn}$ in carbonic anhydrase. Zinc forms minerals with a wider range of 313 elements than $\mathrm{Cd}$, but the shared S-containing mineral chemistry, solubility, and localities of the 314 two metals enhanced their biogeochemical link. The ability of diatoms to use $\mathrm{Cd}$ as a cofactor in 315 carbonic anhydrase during a period of dramatic change in the geosphere and biosphere, supported 316 carbon fixation by diatoms during periods of $\mathrm{Zn}$ scarcity. Alterations to the biogeochemical cycles 317 of $\mathrm{Zn}$ and $\mathrm{Cd}$ exemplify the importance of the coevolution of the geosphere and biosphere in 318 shaping primary production in the modern ocean.

\section{Acknowledgements}

There are no financial conflicts of interest for any author of this study. Data presented in

321 this manuscript can be accessed from the Mineral Evolution Database [MED; (Golden et al. 2019);

322 http://rruff.info/evolution/]. We also acknowledge Josh Golden and Robert Downs at the 323 University of Arizona, and Chao Liu and Robert Hazen from the Carnegie Geophysical Laboratory 324 for data support with the MED and helpful insight. dragon is freely available as an open-source R 
325 package and is accessible from CRAN (https://cran.r-project.org/) to analyze data from 326 the Mineral Evolution Database. This project was funded in part by the Rowan University Seed 327 Program, the Rowan University Department of Biological Sciences Undergraduate Summer 328 Research Fellowship that is partially supported by the New Jersey Space Grant, the NASA 329 Astrobiology Institute (Cycle 8) ENIGMA: Evolution of Nanomachines In Geospheres and 330 Microbial Ancestors (80NSSC18M0093), and the 4D Deep-Time Data Driven Initiative at the 331 Carnegie Institution for Science. 


\section{References}

Ahner, Beth A., Shing Kong, and Fraçois M. M. Morel. 1995. "Phytochelatin Production in Marine Algae. 1. An Interspecies Comparison." Limnology and Oceanography 40 (4): 649-57. https://doi.org/10.4319/1o.1995.40.4.0649.

Al-Farawati, Radwan, and Constant M. G. van den Berg. 1999. "Metal-Sulfide Complexation in Seawater.” Marine Chemistry 63 (3): 331-52. https://doi.org/10.1016/S03044203(98)00056-5.

Alterio, Vincenzo, Emma Langella, Giuseppina De Simone, and Simona Maria Monti. 2015. "Cadmium-Containing Carbonic Anhydrase CDCA1 in Marine Diatom Thalassiosira Weissflogii." Marine Drugs 13 (4): 1688-97. https://doi.org/10.3390/md13041688.

Alterio, Vincenzo, Emma Langella, Francesca Viparelli, Daniela Vullo, Giuseppina Ascione, Nina A. Dathan, François M. M. Morel, Claudiu T. Supuran, Giuseppina De Simone, and Simona Maria Monti. 2012. "Structural and Inhibition Insights into Carbonic Anhydrase CDCA1 from the Marine Diatom Thalassiosira Weissflogii." Biochimie 94 (5): 1232-41. https://doi.org/10.1016/j.biochi.2012.02.013.

Amata, Orazio, Tiziana Marino, Nino Russo, and Marirosa Toscano. 2011. "Catalytic Activity of a $\zeta$-Class Zinc and Cadmium Containing Carbonic Anhydrase . Compared Work Mechanisms." Physical Chemistry Chemical Physics 13 (8): 3468-77. https://doi.org/10.1039/C0CP01053G.

Armbrust, E. Virginia. 2009. "The Life of Diatoms in the World's Oceans." Nature 459 (7244): 185-92. https://doi.org/10.1038/nature08057.

Badger, M R, and G D Price. 1994. "The Role of Carbonic Anhydrase in Photosynthesis." Annual Review of Plant Physiology and Plant Molecular Biology 45 (1): 369-92. https://doi.org/10.1146/annurev.pp.45.060194.002101.

Barrow, N. J., J. Gerth, and G. W. Brümmer. 1989. "Reaction Kinetics of the Adsorption and Desorption of Nickel, Zinc and Cadmium by Goethite. II Modelling the Extent and Rate of Reaction." Journal of Soil Science 40 (2): 437-50. https://doi.org/10.1111/j.13652389.1989.tb01286.x.

Berner, Robert A. 1992. "Weathering, Plants, and the Long-Term Carbon Cycle." Geochimica et Cosmochimica Acta 56 (8): 3225-31. https://doi.org/10.1016/0016-7037(92)90300-8.

Bertine, K. K., and Edward D. Goldberg. 1971. "Fossil Fuel Combustion and the Major Sedimentary Cycle." Science 173 (3993): 233-35. https://doi.org/10.1126/science.173.3993.233.

Beyersmann, Detmar, and Stefan Hechtenberg. 1997. "Cadmium, Gene Regulation, and Cellular Signalling in Mammalian Cells." Toxicology and Applied Pharmacology 144 (2): 247 61. https://doi.org/10.1006/taap.1997.8125.

Blondel, Vincent D., Jean-Loup Guillaume, Renaud Lambiotte, and Etienne Lefebvre. 2008. "Fast Unfolding of Communities in Large Networks." Journal of Statistical Mechanics: Theory and Experiment 2008 (10): P10008. https://doi.org/10.1088/17425468/2008/10/P10008.

Boyle, E. A., F. Sclater, and J. M. Edmond. 1976. "On the Marine Geochemistry of Cadmium." Nature 263 (5572): 42-44. https://doi.org/10.1038/263042a0.

Bruemmer, G. W., J. Gerth, and K. G. Tiller. 1988. "Reaction Kinetics of the Adsorption and Desorption of Nickel, Zinc and Cadmium by Goethite. I. Adsorption and Diffusion of 
Metals.” Journal of Soil Science 39 (1): 37-52. https://doi.org/10.1111/j.13652389.1988.tb01192.x.

Callender, E. 2003. “Treatise on Geochemistry.” In , Holland, H.D, Turekian, K.K., 9:67-105. Pergamon, Oxford.

Canfield, D. E. 1998. “A New Model for Proterozoic Ocean Chemistry." Nature 396 (6710): 450-53. https://doi.org/10.1038/24839.

Canfield, Don E., Simon W. Poulton, and Guy M. Narbonne. 2007. "Late-Neoproterozoic DeepOcean Oxygenation and the Rise of Animal Life." Science 315 (5808): 92-95. https://doi.org/10.1126/science.1135013.

Clauset, Aaron, M. E. J. Newman, and Cristopher Moore. 2004. "Finding Community Structure in Very Large Networks." Physical Review E 70 (6): 066111. https://doi.org/10.1103/PhysRevE.70.066111.

Coale, Kenneth H. 1991. "Effects of Iron, Manganese, Copper, and Zinc Enrichments on Productivity and Biomass in the Subarctic Pacific." Limnology and Oceanography 36 (8): 1851-64. https://doi.org/10.4319/lo.1991.36.8.1851.

Coogan, Timothy P., Robert M. Bare, and Michael P. Waalkes. 1992. "Cadmium-Induced DNA Strand Damage in Cultured Liver Cells: Reduction in Cadmium Genotoxicity Following Zinc Pretreatment." Toxicology and Applied Pharmacology 113 (2): 227-33. https://doi.org/10.1016/0041-008X(92)90118-C.

Cook, Nigel J., Cristiana L. Ciobanu, Allan Pring, William Skinner, Masaaki Shimizu, Leonid Danyushevsky, Bernhardt Saini-Eidukat, and Frank Melcher. 2009. "Trace and Minor Elements in Sphalerite: A LA-ICPMS Study." Geochimica et Cosmochimica Acta 73 (16): 4761-91. https://doi.org/10.1016/j.gca.2009.05.045.

Crawford, D. W., M. S. Lipsen, D. A. Purdie, M. C. Lohan, P. J. Statham, F. A. Whitney, J. N. Putland, et al. 2003. "Influence of Zinc and Iron Enrichments on Phytoplankton Growth in the Northeastern Subarctic Pacific." Limnology and Oceanography 48 (4): 1583-1600. https://doi.org/10.4319/lo.2003.48.4.1583.

Cullen, Jay T., and Maria T. Maldonado. 2013. "Biogeochemistry of Cadmium and Its Release to the Environment." Metal Ions in Life Sciences 11: 31-62. https://doi.org/10.1007/978-94007-5179-8_2.

Cutter, Gregory A, Russell S. Walsh, and Catarina Silva de Echols. 1999. "Production and Speciation of Hydrogen Sulfide in Surface Waters of the High Latitude North Atlantic Ocean.” Deep Sea Research Part II: Topical Studies in Oceanography 46 (5): 991-1010. https://doi.org/10.1016/S0967-0645(99)00013-2.

Das, P., S. Samantaray, and G. R. Rout. 1997. "Studies on Cadmium Toxicity in Plants: A Review." Environmental Pollution 98 (1): 29-36.

Day, Richard, and Jane Franklin. 1946. "Plant Carbonic Anhydrase." Science 104 (2703): 36365.

Dey, Abhishek, Francis E. Jenney, Michael W. W. Adams, Elena Babini, Yasuhiro Takahashi, Keiichi Fukuyama, Keith O. Hodgson, Britt Hedman, and Edward I. Solomon. 2007. "Solvent Tuning of Electrochemical Potentials in the Active Sites of HiPIP Versus Ferredoxin." Science 318 (5855): 1464-68. https://doi.org/10.1126/science.1147753.

Douville, E, J. L Charlou, E. H Oelkers, P Bienvenu, C. F Jove Colon, J. P Donval, Y Fouquet, D Prieur, and P Appriou. 2002. "The Rainbow Vent Fluids ( $36^{\circ} 14$ 'N, MAR): The Influence of Ultramafic Rocks and Phase Separation on Trace Metal Content in Mid- 
Atlantic Ridge Hydrothermal Fluids.” Chemical Geology 184 (1): 37-48. https://doi.org/10.1016/S0009-2541(01)00351-5.

Duce, R. A., P. S. Liss, J. T. Merrill, E. L. Atlas, P. Buat-Menard, B. B. Hicks, J. M. Miller, et al. 1991. "The Atmospheric Input of Trace Species to the World Ocean." Global Biogeochemical Cycles 5 (3): 193-259. https://doi.org/10.1029/91GB01778.

Dupont, Christopher L., Andrew Butcher, Ruben E. Valas, Philip E. Bourne, and Gustavo Caetano-Anollés. 2010. "History of Biological Metal Utilization Inferred through Phylogenomic Analysis of Protein Structures." Proceedings of the National Academy of Sciences 107 (23): 10567-72. https://doi.org/10.1073/pnas.0912491107.

Dupont, Christopher L., Song Yang, Brian Palenik, and Philip E. Bourne. 2006. "Modern Proteomes Contain Putative Imprints of Ancient Shifts in Trace Metal Geochemistry." Proceedings of the National Academy of Sciences 103 (47): 17822-27. https://doi.org/10.1073/pnas.0605798103.

Falkowski, Paul G., and Andrew H. Knoll. 2007. Evolution of Primary Producers in the Sea. Edited by Paul G. Falkowski and Andrew H. Knoll. Burlington: Academic Press. https://doi.org/10.1016/B978-012370518-1/50002-3.

Farquhar, James, Huiming Bao, and Mark Thiemens. 2000. “Atmospheric Influence of Earth's Earliest Sulfur Cycle.” Science 289 (5480): 756-58. https://doi.org/10.1126/science.289.5480.756.

Farquhar, James, and Boswell A Wing. 2003. "Multiple Sulfur Isotopes and the Evolution of the Atmosphere." Earth and Planetary Science Letters 213 (1): 1-13. https://doi.org/10.1016/S0012-821X(03)00296-6.

Fike, D. A., J. P. Grotzinger, L. M. Pratt, and R. E. Summons. 2006. "Oxidation of the Ediacaran Ocean.” Nature 444 (7120): 744-47. https://doi.org/10.1038/nature05345.

Fleischer, M., A. F. Sarofim, D. W. Fassett, P. Hammond, H. T. Shacklette, I. C. Nisbet, and S. Epstein. 1974. "Environmental Impact of Cadmium: A Review by the Panel on Hazardous Trace Substances." Environmental Health Perspectives 7: 232-53.

Flick, D. F., H. F. Kraybill, and J. M. Dlmitroff. 1971. "Toxic Effects of Cadmium: A Review." Environmental Research 4 (2): 71-85. https://doi.org/10.1016/0013-9351(71)90036-3.

Furnas, Miles J. 1990. "In Situ Growth Rates of Marine Phytoplankton: Approaches to Measurement, Community and Species Growth Rates.” Journal of Plankton Research 12 (6): 1117-51. https://doi.org/10.1093/plankt/12.6.1117.

Gerth, J., and G. Brümmer. 1983. "Adsorption und Festlegung von Nickel, Zink und Cadmium durch Goethit ( $\alpha-\mathrm{FeOOH})$." Fresenius' Zeitschrift für analytische Chemie 316 (6): 61620. https://doi.org/10.1007/BF00492275.

Giaginis, Constantinos, Elisavet Gatzidou, and Stamatios Theocharis. 2006. "DNA Repair Systems as Targets of Cadmium Toxicity." Toxicology and Applied Pharmacology 213 (3): 282-90. https://doi.org/10.1016/j.taap.2006.03.008.

Golden, Joshua J., Robert T. Downs, Robert M. Hazen, Alexander J. Pires, and Jolyon Ralph. 2019. "Mineral Evolution Database: Data-Driven Age Assignment, How Does a Mineral Get an Age?" In GSA Annual Meeting. Phoenix, Arizona. https://doi.org/doi: 10.1130/abs/2019AM-334056.

Gong, Henry, Arthur W. Rose, and Norman H. Suhr. 1977. "The Geochemistry of Cadmium in Some Sedimentary Rocks.” Geochimica et Cosmochimica Acta 41 (12): 1687-92. https://doi.org/10.1016/0016-7037(77)90200-9. 
Grill, Erwin, Susanne Löffler, Ernst-L. Winnacker, and Meinhart H. Zenk. 1989. "Phytochelatins, the Heavy-Metal-Binding Peptides of Plants, Are Synthesized from Glutathione by a Specific $\gamma$-Glutamylcysteine Dipeptidyl Transpeptidase (Phytochelatin Synthase)." Proceedings of the National Academy of Sciences 86 (18): 6838-42. https://doi.org/10.1073/pnas.86.18.6838.

Grill, Erwin, Ernst-L. Winnacker, and Meinhart H. Zenk. 1985. "Phytochelatins: The Principal Heavy-Metal Complexing Peptides of Higher Plants." Science 230 (4726): 674-76. https://doi.org/10.1126/science.230.4726.674.

Hazen, Robert M., Robert T. Downs, Ahmed Eleish, Peter Fox, Olivier C. Gagné, Joshua J. Golden, Edward S. Grew, et al. 2019. "Data-Driven Discovery in Mineralogy: Recent Advances in Data Resources, Analysis, and Visualization." Engineering 5 (3): 397-405. https://doi.org/10.1016/j.eng.2019.03.006.

Holm, Richard H., Pierre Kennepohl, and Edward I. Solomon. 1996. "Structural and Functional Aspects of Metal Sites in Biology." Chemical Reviews 96 (7): 2239-2314. https://doi.org/10.1021/cr9500390.

Horner, Tristan J., Renee B. Y. Lee, Gideon M. Henderson, and Rosalind E. M. Rickaby. 2013. "Nonspecific Uptake and Homeostasis Drive the Oceanic Cadmium Cycle." Proceedings of the National Academy of Sciences 110 (7): 2500-2505.

Hosseinzadeh, Parisa, and Yi Lu. 2016. "Design and Fine-Tuning Redox Potentials of Metalloproteins Involved in Electron Transfer in Bioenergetics." Biochimica et Biophysica Acta (BBA) - Bioenergetics, Biodesign for Bioenergetics - the design and engineering of electron transfer cofactors, proteins and protein networks, 1857 (5): 55781. https://doi.org/10.1016/j.bbabio.2015.08.006.

Hystad, Grethe, Shaunna M. Morrison, and Robert M. Hazen. 2019. "Statistical Analysis of Mineral Evolution and Mineral Ecology: The Current State and a Vision for the Future." Applied Computing and Geosciences 1 (October): 100005. https://doi.org/10.1016/j.acags.2019.100005.

Kelly, S. D., M. Boyanov, B. Bunker, J. B. Fein, D. A. Fowle, N. Yee, K. M. Kemner, and IUCr. 2001. "XAFS Determination of the Bacterial Cell Wall Functional Groups Responsible for Complexation of $\mathrm{Cd}$ and $\mathrm{U}$ as a Function of PH." Journal of Synchrotron Radiation, March. https://doi.org/10.1107/S0909049500021014.

Khan, Muhammad Daud, Lei Mei, Basharat Ali, Yue Chen, Xin Cheng, and S. J. Zhu. 2013. "Cadmium-Induced Upregulation of Lipid Peroxidation and Reactive Oxygen Species Caused Physiological, Biochemical, and Ultrastructural Changes in Upland Cotton Seedlings.” Research article. BioMed Research International. 2013. https://doi.org/10.1155/2013/374063.

Kooistra, Wiebe H. C. F., and Linda K. Medlin. 1996. "Evolution of the Diatoms (Bacillariophyta): IV. A Reconstruction of Their Age from Small Subunit RRNA Coding Regions and the Fossil Record." Molecular Phylogenetics and Evolution 6 (3): 391-407. https://doi.org/10.1006/mpev.1996.0088.

Lane, Todd W., and François M. M. Morel. 2000. "A Biological Function for Cadmium in Marine Diatoms." Proceedings of the National Academy of Sciences 97 (9): 4627-31. https://doi.org/10.1073/pnas.090091397.

Lane, Todd W., Mak A. Saito, Graham N. George, Ingrid J. Pickering, Roger C. Prince, and François M. M. Morel. 2005. "A Cadmium Enzyme from a Marine Diatom.” Nature 435 (7038): 42-42. https://doi.org/10.1038/435042a. 
Lee, Jennifer G., Beth A. Ahner, and François M. M. Morel. 1996. "Export of Cadmium and Phytochelatin by the Marine Diatom Thalassiosira Weissflogii." Environmental Science \& Technology 30 (6): 1814-21. https://doi.org/10.1021/es950331p.

Lock, Koen, and Colin R. Janssen. 2003. "Influence of Aging on Metal Availability in Soils." In Reviews of Environmental Contamination and Toxicology, edited by George W. Ware, 121. Reviews of Environmental Contamination and Toxicology. New York, NY: Springer New York. https://doi.org/10.1007/0-387-21728-2_1.

Luther, George W., David T. Rickard, Stephen Theberge, and Anthony Olroyd. 1996. "Determination of Metal (Bi)Sulfide Stability Constants of Mn2+, Fe2+, Co2+, Ni2+, $\mathrm{Cu} 2+$, and Zn2+ by Voltammetric Methods." Environmental Science \& Technology 30 (2): 671-79. https://doi.org/10.1021/es950417i.

Mahadevan, Amala, Eric D’Asaro, Craig Lee, and Mary Jane Perry. 2012. "Eddy-Driven Stratification Initiates North Atlantic Spring Phytoplankton Blooms.” Science 337 (6090): 54-58. https://doi.org/10.1126/science.1218740.

Meldrum, N. U., and F. J. W. Roughton. 1933. "Carbonic Anhydrase. Its Preparation and Properties." The Journal of Physiology 80 (2): 113-42. https://doi.org/10.1113/jphysiol.1933.sp003077.

Milligan, W. O. 1934. "The Color and Crystal Structure of Precipitated Cadmium Sulfide." The Journal of Physical Chemistry 38 (6): 797-800.

Moore, Eli K., Jihua Hao, Anirudh Prabhu, Hao Zhong, Ben I. Jelen, Mike Meyer, Robert M. Hazen, and Paul G. Falkowski. 2018. "Geological and Chemical Factors That Impacted the Biological Utilization of Cobalt in the Archean Eon." Journal of Geophysical Research: Biogeosciences 123 (3): 743-59. https://doi.org/10.1002/2017JG004067.

Moore, Eli K., Jihua Hao, Stephanie J. Spielman, and Nathan Yee. 2020. "The Evolving Redox Chemistry and Bioavailability of Vanadium in Deep Time." Geobiology 18 (2): 127-38. https://doi.org/10.1111/gbi.12375.

Moore, Eli K., Benjamin I. Jelen, Donato Giovannelli, Hagai Raanan, and Paul G. Falkowski. 2017. "Metal Availability and the Expanding Network of Microbial Metabolisms in the Archaean Eon.” Nature Geoscience 10 (9): 629-36. https://doi.org/10.1038/ngeo3006.

Moroney, J. V., S. G. Bartlett, and G. Samuelsson. 2001. "Carbonic Anhydrases in Plants and Algae." Plant, Cell \& Environment 24 (2): 141-53. https://doi.org/10.1111/j.13653040.2001.00669.x.

Morrison, Shaunna M., Chao Liu, Ahmed Eleish, Anirudh Prabhu, Congrui Li, Jolyon Ralph, Robert T. Downs, et al. 2017. "Network Analysis of Mineralogical Systems." American Mineralogist 102 (8): 1588-1596. https://doi.org/10.2138/am-2017-6104CCBYNCND.

Nriagu, J. O. 1980. Cadmium in the Environment, Part I: Ecological Cycling. New York, NY: John Wiley \& Sons.

Nriagu, Jerome O. 1989. "A Global Assessment of Natural Sources of Atmospheric Trace Metals.” Nature 338 (6210): 47-49. https://doi.org/10.1038/338047a0.

Park, Haewon, Bongkeun Song, and François M. M. Morel. 2007. "Diversity of the CadmiumContaining Carbonic Anhydrase in Marine Diatoms and Natural Waters." Environmental Microbiology 9 (2): 403-13. https://doi.org/10.1111/j.1462-2920.2006.01151.x.

Pinter, Tyler B. J., and Martin J. Stillman. 2014. "The Zinc Balance: Competitive Zinc Metalation of Carbonic Anhydrase and Metallothionein 1A." Biochemistry 53 (39): 6276-85. https://doi.org/10.1021/bi5008673. 
Poulton, Simon W., Philip W. Fralick, and Donald E. Canfield. 2004. "The Transition to a Sulphidic Ocean 1.84 Billion Years Ago.” Nature 431 (7005): 173-77. https://doi.org/10.1038/nature02912.

Price, N. M., and F. M. M. Morel. 1990. "Cadmium and Cobalt Substitution for Zinc in a Marine Diatom.” Nature 344 (6267): 658-60. https://doi.org/10.1038/344658a0.

Rapp, Robert P., and E. Bruce Watson. 1995. "Dehydration Melting of Metabasalt at 8-32 Kbar: Implications for Continental Growth and Crust-Mantle Recycling.” Journal of Petrology 36 (4): 891-931. https://doi.org/10.1093/petrology/36.4.891.

Rittner, E. S., and J. H. Schulman. 1943. "Studies on the Coprecipitation of Cadmium and Mercuric Sulfides." The Journal of Physical Chemistry 47 (8): 537-43.

Robson, T. C., C. B. Braungardt, J. Rieuwerts, and P. Worsfold. 2014. "Cadmium Contamination of Agricultural Soils and Crops Resulting from Sphalerite Weathering." Environmental Pollution 184 (January): 283-89. https://doi.org/10.1016/j.envpol.2013.09.001.

Rosenbusch, Jurg P., and Klaus Weber. 1971. "Localization of the Zinc Binding Site of Aspartate Transcarbamoylase in the Regulatory Subunit." Proceedings of the National Academy of Sciences 68 (5): 1019-23. https://doi.org/10.1073/pnas.68.5.1019.

Rowlett, Roger S. 2010. "Structure and Catalytic Mechanism of the $\beta$-Carbonic Anhydrases." Biochimica et Biophysica Acta (BBA) - Proteins and Proteomics, Carbonic Anhydrase and Superoxide Dismutase, 1804 (2): 362-73. https://doi.org/10.1016/j.bbapap.2009.08.002.

Sahoo, Swapan K., Noah J. Planavsky, Brian Kendall, Xinqiang Wang, Xiaoying Shi, Clint Scott, Ariel D. Anbar, Timothy W. Lyons, and Ganqing Jiang. 2012. "Ocean Oxygenation in the Wake of the Marinoan Glaciation.” Nature 489 (7417): 546-49. https://doi.org/10.1038/nature11445.

Saito, Mak A, Daniel M Sigman, and François M. M Morel. 2003. "The Bioinorganic Chemistry of the Ancient Ocean: The Co-Evolution of Cyanobacterial Metal Requirements and Biogeochemical Cycles at the Archean-Proterozoic Boundary?" Inorganica Chimica Acta, Protagonists in Chemistry, Frausto Da Silva, 356 (December): 308-18. https://doi.org/10.1016/S0020-1693(03)00442-0.

Schmöger, Marcus E. V., Matjaz Oven, and Erwin Grill. 2000. "Detoxification of Arsenic by Phytochelatins in Plants." Plant Physiology 122 (3): 793-802. https://doi.org/10.1104/pp.122.3.793.

Scott, C., T. W. Lyons, A. Bekker, Y. Shen, S. W. Poulton, X. Chu, and A. D. Anbar. 2008. "Tracing the Stepwise Oxygenation of the Proterozoic Ocean." Nature 452 (7186): 45659. https://doi.org/10.1038/nature06811.

Shen, Yanan, Roger Buick, and Donald E. Canfield. 2001. "Isotopic Evidence for Microbial Sulphate Reduction in the Early Archaean Era." Nature 410 (6824): 77-81. https://doi.org/10.1038/35065071.

Sigg, Laura, and Renata Behra. 2005. "Speciation and Bioavailability of Trace Metals in Freshwater Environments." In Metal Ions in Biological Systems, 44:47-73. CRC Press.

Sims, Patricia A., David G. Mann, and Linda K. Medlin. 2006. "Evolution of the Diatoms: Insights from Fossil, Biological and Molecular Data." Phycologia 45 (4): 361-402. https://doi.org/10.2216/05-22.1.

Spielman, Stephanie J. 2019. Dragon: Deep Time Redox Analysis of the Geobiology Ontology Network (version R Package version 0.2.1). Dragon. https:/CRAN.Rproject.org/package $=$ dragon. 
Stanton, Mark R. 2005. "Baseline Laboratory Studies of Sphalerite (ZnS) Dissolution: Effects on Aqueous Metal Concentrations and Solubilization Rates.” American Society of Mining and Reclamation 1: 1155-65. https://doi.org/doi:10.21000/JASMR0501155.

Sültemeyer, Dieter. 1998. "Carbonic Anhydrase in Eukaryotic Algae: Characterization, Regulation, and Possible Function during Photosynthesis." Canadian Journal of Botany 76 (6): 962-72. https://doi.org/10.1139/b98-082.

Supuran, Claudiu T. 2016. "Structure and Function of Carbonic Anhydrases." Biochemical Journal 473 (14): 2023-32. https://doi.org/10.1042/BCJ20160115.

Taylor, Stuart Ross, and Scott M. McLennan. 1995. "The Geochemical Evolution of the Continental Crust." Reviews of Geophysics 33 (2): 241-65. https://doi.org/10.1029/95RG00262.

Uraguchi, Shimpei, Nobuhiro Tanaka, Christian Hofmann, Kaho Abiko, Naoko Ohkama-Ohtsu, Michael Weber, Takehiro Kamiya, et al. 2017. "Phytochelatin Synthase Has Contrasting Effects on Cadmium and Arsenic Accumulation in Rice Grains." Plant and Cell Physiology 58 (10): 1730-42. https://doi.org/10.1093/pcp/pcx114.

Vance, Derek, Susan H. Little, Gregory F. de Souza, Samar Khatiwala, Maeve C. Lohan, and Rob Middag. 2017. "Silicon and Zinc Biogeochemical Cycles Coupled through the Southern Ocean.” Nature Geoscience 10 (3): 202-6. https://doi.org/10.1038/ngeo2890.

Wang, Mengjiao, and Wen-Xiong Wang. 2008. "Cadmium Toxicity in a Marine Diatom as Predicted by the Cellular Metal Sensitive Fraction." Environmental Science \& Technology 42 (3): 940-46. https://doi.org/10.1021/es0719273.

Wedepohl, K. H. 1995. "The Composition of the Continental Crust." Geochimica et Cosmochimica Acta 59 (7): 1217-32. https://doi.org/10.1016/0016-7037(95)00038-2.

Wilbur, Karl M., and Norman G. Anderson. 1948. "Electrometric and Colorimetric Determination of Carbonic Anhydrase.” Journal of Biological Chemistry 176 (1): 14754.

Wu, Yun, Zhiqiang Guo, Wei Zhang, Qiaoguo Tan, Li Zhang, Xinlei Ge, and Mindong Chen. 2016. "Quantitative Relationship between Cadmium Uptake and the Kinetics of Phytochelatin Induction by Cadmium in a Marine Diatom." Scientific Reports 6 (October): 35935. https://doi.org/10.1038/srep35935.

Xu, Yan, Liang Feng, Philip D. Jeffrey, Yigong Shi, and François M. M. Morel. 2008. "Structure and Metal Exchange in the Cadmium Carbonic Anhydrase of Marine Diatoms." Nature 452 (7183): 56-61. https://doi.org/10.1038/nature06636.

Yee, Nathan, and Jeremy Fein. 2001. "Cd Adsorption onto Bacterial Surfaces: A Universal Adsorption Edge?" Geochimica et Cosmochimica Acta 65 (13): 2037-42. https://doi.org/10.1016/S0016-7037(01)00587-7.

Yi, Wen, Alex N. Halliday, Jeff C. Alt, Der-Chuen Lee, Mark Rehkämper, Michael O. Garcia, C. H. Langmuir, and Yongjun Su. 2000. "Cadmium, Indium, Tin, Tellurium, and Sulfur in Oceanic Basalts: Implications for Chalcophile Element Fractionation in the Earth." Journal of Geophysical Research: Solid Earth 105 (B8): 18927-48. https://doi.org/10.1029/2000JB900152.

Zhang, Jia-Zhong, and Frank J. Millero. 1994. "Investigation of Metal Sulfide Complexes in Sea Water Using Cathodic Stripping Square Wave Voltammetry." Analytica Chimica Acta 284 (3): 497-504. https://doi.org/10.1016/0003-2670(94)85056-9. 


\section{Figure Captions}

648 Figure 1. Expanding bipartite mineral chemistry networks depicting all known Cd minerals and

649 their constituent elements at specific time periods $[($ Golden et al. 2019)

650 http://rruff.info/evolution/]. (a) All Cd minerals with maximum known ages $\geq 2.7$ billion years ago

$651(\mathrm{Ga}) ;(\mathbf{b}) \geq 0.6 \mathrm{Ga} ;(\mathbf{c}) \geq 0.2 \mathrm{Ga} ;(\mathbf{d})$ Present day. Mineral nodes are represented by circles (color

652 represents maximum known mineral ages). Element nodes are represented by their chemical 653 symbols. Mineral nodes have network connections (referred to as "edges"; edges are unweighted)

654 to each of their constituent elements. For example, greenockite (CdS) has network edges connected 655 to $\mathrm{Cd}$ and S. Mineral nodes are sized by number of known localities, and element nodes are sized 656 by number of network edges (i.e., the number of minerals which contain that element). Networks 657 were created using the dragon R package (Spielman 2019).

658 Figure 2. $\mathrm{Cd}$ and $\mathrm{Zn}$ bipartite mineral chemistry network at present day containing all known $\mathrm{Zn}$ 659 and Cd minerals and their constituent elements. Mineral nodes are sized by number of localities 660 and colored by maximum known age. Element nodes are sized by number of network edges.

661 Figure 3. $\mathrm{Cd}$ and $\mathrm{Zn}$ bipartite mineral chemistry network at present day containing all known $\mathrm{Zn}$ 662 and Cd minerals and their constituent elements. Mineral nodes and element nodes are colored by 663 Louvain community detection clusters (Blondel et al. 2008). Mineral are sized by number of 664 localities and element nodes are sized by number of network edges.

665 Figure 4: Total number of localities that S-containing Cd minerals and S-containing Zn minerals 666 co-occur at (brown triangles), and total number of localities that non-S-containing Cd minerals 
667 and non-S-containing Zn minerals co-occur at (black squares) through geologic time. First GOE = 668 Great Oxidation Event (Farquhar, Bao, and Thiemens 2000; Farquhar and Wing 2003); Second 669 GOE (Fike et al. 2006; Don E. Canfield, Poulton, and Narbonne 2007; Sahoo et al. 2012); Oldest 670 diatom fossils (Kooistra and Medlin 1996; Sims, Mann, and Medlin 2006; Falkowski and Knoll 671 2007).

672 Figure 5. Cadmium and zinc bipartite mineral chemistry networks at present day containing all 673 known $\mathrm{Zn}$ and $\mathrm{Cd}$ minerals and their constituent elements. Mineral nodes are sized by number of 674 localities and colored by mean element electronegativity. Element nodes are sized by number of 675 network edges. (a) Cadmium minerals and their constituent elements are highlighted. (b) Zinc 676 minerals and their constituent elements are highlighted.

677 Figure 6. Plot of mean mineral electronegativity by maximum mineral age in billions of years 678 (Ga) for (a) minerals that contain $\mathrm{Cd}$; (b) minerals that contain both $\mathrm{Zn}$ and $\mathrm{S}$; and (c) minerals 679 that contain Zn. Mean mineral electronegativity is calculated as an unweighted average of each 680 mineral's constituent element electronegativities. 